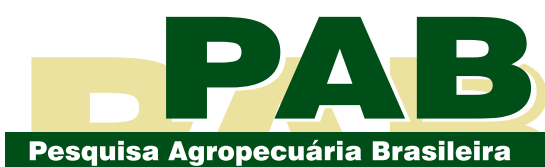

ISSN 1678-3921

Journal homepage: www.embrapa.br/pab

For manuscript submission and journal contents, access: www.scielo.br/pab
Pomology/ Original Article

\section{Performance of 'Jaffa' sweet orange on different rootstocks for orchards in the Brazilian Northeast}

\begin{abstract}
The objective of this work was to evaluate the effect of nine rootstocks on 'Jaffa' sweet orange (Citrus sinensis) for its vegetative, productive, and qualitative traits, and for its susceptibility to three pest mites (Eutetranychus banksi, Tetranychus mexicanus and Phyllocoptruta oleivora). The following parameters were evaluated: vegetative growth, yield, physiochemical characteristics of fruit, and density of pest mites. 'Sunki Tropical' mandarin conferred high cumulative yields whereas 'Orlando' tangelo and 'Rugoso Vermelho' lemon imparted bigger fruit with low brix, and less acidity to 'Jaffa'. Indio and 'Riverside' citrandarins induced more acid fruit of smaller sizes, as well as low-cumulated yields and canopy volumes. Also, the 'Cravo Santa Cruz' lime, 'San Diego' citrandarin, and the hybrids HTR-051 and LVK x LCR-010 conferred lower-cumulated yields to 'Jaffa'. The rootstocks did not influence the population levels of the evaluated mites. 'Sunki Tropical' mandarin, 'Cravo Santa Cruz' lime and 'Rugoso Vermelho' lemon stand up as excellent rootstock options for 'Jaffa' sweet orange in the Northeastern Brazil.
\end{abstract}

Index terms: Citrus sinensis, juice content, yield, phytophagous mites.

\section{Desempenho da laranjeira 'Jaffa' em diferentes porta-enxertos para pomares do nordeste Brasileiro}

Resumo - O objetivo deste trabalho foi avaliar o efeito de nove porta-enxertos sobre os parâmetros vegetativos, produtivos e qualitativos da laranjeiradoce 'Jaffa' (Citrus sinensis) e sobre a sua suscetibilidade a três ácaros-praga (Eutetranychus banksi, Tetranychus mexicanus e Phyllocoptruta oleivora). Os seguintes parâmetros foram avaliados: crescimento vegetativo, produtividade, características fisioquímicas dos frutos e densidade de ácaros-praga. A tangerineira 'Sunki Tropical' conferiu elevada produtividade à laranjeira 'Jaffa', enquanto o tangeleiro 'Orlando' e o limoeiro 'Rugoso Vermelho' induziram frutos maiores, com baixos valores Brix e menos ácidos à laranjeira 'Jaffa'. Os citrandarins 'Indio' e 'Riverside' induziram frutos mais ácidos e de tamanhos menores, assim como baixa produtividade acumulada e menor copa. Adicionalmente, o limoeiro 'Cravo Santa Cruz', o citrandarin 'San Diego' e os híbridos HTR-051 e LVK x LCR-010 conferiram menor produção acumulada à laranjeira 'Jaffa'. Os porta-enxertos não influenciaram os níveis populacionais dos ácaros avaliados. A tangerineira 'Sunki Tropical', o limoeiro 'Cravo Santa Cruz' e o limoeiro 'Rugoso Vermelho' se destacam como excelentes opções de porta-enxertos para a laranjeira 'Jaffa' na região Nordeste do Brasil.

Termos para indexação: Citrus sinensis, conteúdo de suco, produtividade, ácaros fitófagos. 


\section{Introduction}

Brazil ranks first in the production of sweet orange in the world, and Brazilian Southeast and Northeast are the main producing regions (IBGE, 2016). In Northeastern Brazil, the majority of orchards cultivate 'Pera' sweet orange [Citrus sinensis (L.) Osbeck] grafted on 'Rangpur' lime (C. limonia Osbeck) because of fruit with good quality and drought tolerance imparted from the rootstock (Almeida \& Passos, 2011). However, such a narrow genetic diversity could lead to losses caused by biotic and abiotic stresses, threatening the whole citrus chain in this region (Carvalho et al., 2019). Accordingly, Embrapa (Brazilian Agricultural Research Corporation) begun field trials to select new scion-rootstock combinations for rainfed citrus groves of the Brazilian Northeast, which resulted in the indication of some cultivars (Carvalho et al., 2016a, 2016b, 2019).

'Jaffa' orange originates from Israel, where it is the most cultivated scion cultivar (Ishfaq et al., 1999). It is characterized by medium-sized plants, with open branches, satisfactory yields, tendency to production alternation, precocious maturation, and fruit suited for both in natura consumption and juice production (Bacar et al., 2017).

Some pests, among which the Texas citrus mite Eutetranychus banksi and the tetranychid Tetranychus mexicanus (Acari: Tetranychidae), as well as the rust mite Phyllocoptruta oleivora (Acari: Eriophyidae) attack citrus orchards in Northeastern Brazil (Teodoro et al., 2014; Silva et al., 2016). While E. banksi and T. mexicanus feed upon leaves of citrus trees, $P$. oleivora is a fruit-attacking pest that leads to reduced yield and aesthetic damage to the fruit that is similar to rust (Teodoro et al., 2014). Therefore, assessing the influence of rootstocks on the susceptibility of scions to pests is highly recommended, as cultivars show distinct genetic characteristics (Vendramim \& Guzzo, 2012; Silva et al., 2016). For instance, densities of $P$. oleivora and T. mexicanus on 'Pera CNPMF D-6' and 'Valencia Tuxpan' sweet oranges were influenced by some rootstocks (Silva et al., 2016).

The objective of this work was to evaluate nine rootstocks on the vegetative, productive, and qualitative traits of 'Jaffa' sweet orange, as well as on the susceptibility of this cultivar to three pest mites.

\section{Materials and Methods}

The experimental orchard was installed in 2008 in an Argissolo Amarelo distrófico (Santos et al., 2013), i.e., a Haplic Acrisol, at the experimental station of Embrapa, located in the municipality of Umbaúba $\left(11^{\circ} 22^{\prime} 37^{\prime \prime S}\right.$, $37^{\circ} 40^{\prime} 26^{\prime \prime} \mathrm{W}$, at $109 \mathrm{~m}$ altitude), in the state of Sergipe, Brazil. Chemical analyses (0-40 cm soil depth) showed the following soil characteristics: $5.04 \mathrm{pH}\left(\mathrm{H}_{2} \mathrm{O}\right), 12.79$ $\mathrm{g} \mathrm{kg}^{-1} \mathrm{OM}, 2.66 \mathrm{mmol}_{\mathrm{c}} \mathrm{dm}^{-3}$ aluminum, $25.49 \mathrm{mmol}_{\mathrm{c}} \mathrm{dm}^{-3}$ calcium, $2.85 \mathrm{mmol}_{\mathrm{c}} \mathrm{dm}^{-3}$ magnesium, $45.19 \mathrm{mg} \mathrm{dm}^{-3}$ phosphorus, $81.25 \mathrm{mg} \mathrm{dm}^{-3}$ potassium, $6.16 \mathrm{mg} \mathrm{dm}^{-3}$ sodium, $56.91 \mathrm{mg} \mathrm{dm}^{-3}$ iron, copper $0.14 \mathrm{mg} \mathrm{dm}^{-3}$, $1.43 \mathrm{mg} \mathrm{dm}^{-3}$ manganese, and $0.36 \mathrm{mg} \mathrm{dm}^{-3}$ zinc. The climate is classified as rainy tropical with a dry summer according to the Köppen-Geiger's classification. Average annual temperature, relative humidity, and rainfall over the experimental period (2008-2016) were $24.6^{\circ} \mathrm{C}, 83 \%$, and $1,274 \mathrm{~mm}$, respectively.

The experiment consisted of 'Jaffa' sweet orange grafted on nine rootstocks, as follows: 'Cravo Santa Cruz' lime (whose common name is Rangpur lime), 'Rugoso Vermelho' lemon (C. jambhiri Lush.), 'Orlando' tangelo (C. paradisi Macfad. x C. tangerina hort. ex Tanaka), 'Sunki Tropical' mandarin [C. sunki (Hayata) hort. ex Tanaka], 'Indio, 'Riverside', and 'San Diego' citrandarins [C. sunki x Poncirus trifoliata (L.) Raf.]), and the hybrids HTR-051 (trifoliate hybrid obtained by using $P$. trifoliata) and LVK x LCR-010 [C. volkameriana $\mathrm{V}$. Ten. \& Pasq. $\mathrm{x}$ 'Rangpur' lime], which were generated in the breeding program of Embrapa Mandioca e Fruticultura. Plant spacing were $6.0 \mathrm{~m} \mathrm{x}$ $4.0 \mathrm{~m}$ (416 plants $\left.\mathrm{ha}^{-1}\right)$ and conventionally managed without irrigation. Management practices included fertilization, control of diseases and weeds, as well as pruning. No control for mites was performed. The experiment consisted of a completely randomized block design, with 9 treatments (rootstocks), 4 replicates, and 4 plants per plot.

Plant height $(\mathrm{PH})$, canopy volume $(\mathrm{CV})$, rootstock/ scion girth ratio $(\mathrm{R} / \mathrm{S})$, and yield efficiency (YE) were measured in 2016, as follows: PH (m) was recorded by using a ruler from the base of the trunk close to the soil up to the top of the plant; $\mathrm{CV}\left(\mathrm{m}^{3}\right)$ was estimated using the expression $\mathrm{CV}=(\pi / 6) \times \mathrm{PH} \times \mathrm{DR} \times \mathrm{DP}$, in which DR and DP are canopy diameters (m) along the row, and in the perpendicular direction to the row, respectively (Cantuarias-Avilés et al., 2012); yields and cumulative yields $\left(\mathrm{CY}\right.$, in $\left.\mathrm{kg} \mathrm{ha}^{-1}\right)$ were evaluated over 6 years (2011 to 2016), while yield efficiency (YE, in

Pesq. agropec. bras., Brasília, v.55, e01665, 2020

DOI: 10.1590/S1678-3921.pab2020.v55.01665 
$\mathrm{kg} \mathrm{m}^{-3}$ ) was estimated by the quotient between the per plant fruit production and CV.

Fruit quality was assessed over 2 years (2014 and 2015) by collecting six fruits per plant (Carvalho et al., 2016a). Briefly, height, rind thickness (mm) and diameter of fruits were measured with a digital caliper (Carvalho et al., 2016a). Juice content was estimated with the equation $\mathrm{JC}=[$ (juice mass $/$ sample mass $) \times$ 100] (Carvalho et al., 2019). Juice mass was obtained by the difference between sample weight and bagasse mass (that is, seeds, peels, and fragments retained in the sieve) (Carvalho et al., 2016a). Total soluble solids (TSS in ${ }^{\circ}$ Brix) were recorded with a digital refractometer with values corrected to $20^{\circ} \mathrm{C}$ (Carvalho et al., 2016a). Titratable acidity (TA, g citric acid $100 \mathrm{~mL}^{-1}$ juice) was determined with a semiautomatic burette with 0.1 mol L-1 $\mathrm{NaOH}$ (titrant) and a phenolphthalein indicator. The ratio was determined as the quotient between TSS and TA (Carvalho et al., 2016a). The content of vitamin $\mathrm{C}$ (mg $100 \mathrm{~mL}^{-1}$ of juice) was calculated using the oxidation-reduction volumetric technique, using $0.002 \mathrm{~mol} \mathrm{~L}^{-1}$ potassium iodate $\left(\mathrm{KIO}_{3}\right)$ and $1 \%$ starch indicator solutions (Carvalho et al., 2016a). Industrial yield was determined with the equation IY $=660 / \mathrm{TI}$, in which TI (technological index) was obtained as juice content $x$ TSS $\times 40.8 / 10.000$, which is equivalent to the amount of TSS in the juice $(\mathrm{kg})$ in a standard $40.8 \mathrm{~kg}$ industrial box of citrus (Carvalho et al., 2016a). Data were subjected to the analysis of variance, followed by Scott-Knott's tests, at 5\% probability.

Multivariate analyses were also performed using XLSTAT (a statistical software for Excel) to identify homogenous groups of rootstocks, considering the universe of all variables that were significant by univariate analysis of variance. At first, a principal component analysis (PCA) was conducted to reduce the dataset into a few synthetic and uncorrelated variables, that is, the first principal components (Carvalho et al., 2019). Then, the rootstocks were grouped by agglomerative hierarchical clustering (AHC) applied on the PCA scores, using the Euclidean distance as a measure of dissimilarity and Ward's minimumvariance method for linkage to identify the clusters (Carvalho et al., 2019). The automatic truncation option was used for cluster splitting. This approach creates homogenous groups based on the largest decrease in the Shannon's entropy between a node and the next one (Carvalho et al., 2019). The resulting clusters were interpreted by means of the PCA results and put into perspective with the results of univariate analyses of variance.

The effect of rootstocks on the population levels of three regional pests of citrus, namely E. banksi, $T$. mexicanus, and P. oleivora was assessed. The number of adults of these mites were monthly recorded from June 2011 to February 2013 (counts of some months were excluded from the analyses as they were null to all rootstocks). In short, E. banksi and T. mexicanus were recorded in four randomly chosen leaves from two plants per plot, totaling 32 leaves per rootstock in each monthly evaluation. For $P$. oleivora, two randomly-chosen fruit taken from two plants per plot were evaluated, totaling 16 fruit per rootstock in each evaluation, and mites were counted in $1 \mathrm{~cm}^{2}$ area. Repeated measures of the analyses of variation, followed by the post hoc Fisher's LSD tests, were carried out to evaluate the effect of rootstocks on the population levels of the pest mites, removing the variance explained by time, as evaluations were conducted monthly. Data were $\sqrt{ }(\mathrm{x})+0.5$ transformed. in order to adjust them for normal distribution (Silva et al., 2016).

\section{Results and discussion}

Rootstocks did not influence the height of 'Jaffa' sweet orange plants, in contrast with the highestcanopy volumes conferred by 'Sunki Tropical' mandarin, 'Rugoso Vermelho' lemon and the hybrid LVK x LCR-010 (Table 1). However, rootstocks did not affect the yield efficiency which considers the yield per volume of canopy.

'Riverside' citrandarin and LVK x LCR-010 induced precocity to 'Jaffa', as yields surpassed 9,500 $\mathrm{kg} \mathrm{ha}^{-1}$ in the first harvest. 'Sunki Tropical' mandarin was related to higher yields throughout harvests and higher cumulative yields, followed by 'Cravo Santa Cruz' lime and 'Rugoso Vermelho' lemon. These results are in line a previous research of our group in the same region, showing that these rootstocks were also recommended for 'Pera CNPMF-D6' sweet orange and 'Piemonte' mandarin [C. clementina hort. ex Tanaka $\mathrm{x}$ tangor 'Murcott' (C. reticulata Blanco x C. sinensis)] (Carvalho et al., 2016a, 2016b).

Except for rind thickness and vitamin $\mathrm{C}$, the rootstocks influenced all qualitative parameters of 'Jaffa' fruit (Table 2). For instance, fruit from trees grafted on HTR-051 yielded less juice, whereas 
'Cravo Santa Cruz' lime induced the highest levels of total soluble solids, but the lowest industrial yield to fruit (Table 2). These results are in agreement with the literature, showing the influence of rootstocks on fruit physiochemical parameters (Carvalho et al., 2016a; Bacar et al., 2017). For instance, 'Cleopatra' (C. reshni hort ex Tanaka) and 'Sunki' mandarins, 'Fepagro C-13' citrange (C. sinensis $\mathrm{x} P$. trifoliata), and 'Swingle' citrumelo induced sweeter fruit to 'Jaffa' than 'Rangpur' lime, in the Brazilian state of Paraná (Bacar et al., 2017).

Values of TA, a proxy for acidity, ranged from 0.86 ('Orlando' tangelo, least acid) to 1.05 ('Indio' citrandarin, most acid), and were similar to those found in Syria for 'Jaffa' (Al-Mouei \& Choumane, 2014), and are within the acceptable limits for oranges (Bacar et al., 2017). Concerning TSS, values ranged from 9.99 ${ }^{\circ}$ Brix ('Orlando' tangelo, least sweet) to $12.21{ }^{\circ} \mathrm{Brix}$ ('Cravo Santa Cruz' lime, most sweet), which are higher than those obtained by Bacar et al. (2017) for 'Jaffa' grafted on five rootstocks, in Paraná state, including 'Rangpur' lime (TSS = 9.10) and 'Sunki' mandarin (TSS =9.46). Such differences may be related to the mean air temperatures during the production period, which is pivotal to form sugars during fruit ripening. Ratio values varied from 10.89 ('Indio' citrandarin) to 12.54 ('Cravo Santa Cruz' lime) and met acceptable standards for oranges (Ceagesp, 2011; Bacar et al., 2017).

'Cravo Santa Cruz' lime, 'Riverside' and 'Indio' citrandarins, 'Sunki Tropical' mandarin, and LVK x

Table 1. Plant height (PH), canopy volume (CV), rootstock/scion girth ratio (R/S), yield efficiency (YE), yield, and on the cumulative yield (CY) of 'Jaffa' sweet orange in relation to rootstocks ${ }^{(1)}$.

\begin{tabular}{|c|c|c|c|c|c|c|c|c|c|c|c|c|}
\hline \multirow[t]{2}{*}{ Rootstocks } & \multirow{2}{*}{$\begin{array}{l}\mathrm{PH} \\
(\mathrm{m})\end{array}$} & \multirow{2}{*}{$\begin{array}{l}\mathrm{CV} \\
\left(\mathrm{m}^{3}\right)\end{array}$} & \multirow[t]{2}{*}{$\mathrm{R} / \mathrm{S}$} & \multicolumn{7}{|c|}{ Yield $\left(\mathrm{kg} \mathrm{ha}^{-1}\right)$} & \multirow{2}{*}{$\begin{array}{c}\mathrm{CY} \\
\left(\mathrm{kg} \mathrm{ha}^{-1}\right)\end{array}$} & \multirow{2}{*}{$\begin{array}{c}\mathrm{YE} \\
\left(\mathrm{kg} \mathrm{m}^{-3}\right)\end{array}$} \\
\hline & & & & 2011 & 2012 & 2013 & 2014 & 2015 & 2016 & 2017 & & \\
\hline Cravo Santa Cruz lime & 2.56 & $12.59 \mathrm{~b}$ & 1.58 & $8,072 b$ & $13,416 \mathrm{a}$ & $13,498 \mathrm{a}$ & $20,571 \mathrm{a}$ & $43,169 \mathrm{c}$ & $34,338 \mathrm{~b}$ & $12,739 a$ & $145,802 b$ & 6.79 \\
\hline Rugoso Vermelho lemon & 2.86 & $16.13 \mathrm{a}$ & 1.41 & $6,365 \mathrm{c}$ & $11,879 \mathrm{a}$ & $11,010 \mathrm{~b}$ & $17,942 \mathrm{a}$ & $47,878 \mathrm{~b}$ & $35,547 \mathrm{~b}$ & $14,708 \mathrm{a}$ & $145,328 b$ & 5.30 \\
\hline Orlando tangelo & 2.73 & $13.46 \mathrm{~b}$ & 1.31 & $7,500 \mathrm{~d}$ & $7,614 b$ & $6,700 \mathrm{c}$ & $9,591 \mathrm{c}$ & $52,478 \mathrm{a}$ & $25,736 \mathrm{~d}$ & $7,515 \mathrm{c}$ & $110,383 d$ & 4.86 \\
\hline Sunki Tropical ma & 3.19 & $17.15 \mathrm{a}$ & 1.49 & $7,857 \mathrm{~b}$ & $13,745 \mathrm{a}$ & $12,740 \mathrm{a}$ & $17,456 \mathrm{a}$ & $56,121 \mathrm{a}$ & $38,861 \mathrm{a}$ & $8,184 \mathrm{c}$ & $157,965 \mathrm{a}$ & 5.60 \\
\hline Indio citrandarin & 2.65 & $12.44 \mathrm{~b}$ & 1.75 & $8,483 b$ & $9,254 \mathrm{~b}$ & $12,483 \mathrm{a}$ & $16,031 \mathrm{a}$ & $34,851 d$ & $24,651 d$ & $5,937 \mathrm{c}$ & $111,689 d$ & 5.27 \\
\hline Riverside citrandarin & 2.74 & $12.39 \mathrm{~b}$ & 1.48 & $10,784 a$ & $9,696 \mathrm{~b}$ & $10,123 b$ & $15,131 \mathrm{~b}$ & $31,432 d$ & $24,806 \mathrm{~d}$ & $8,016 \mathrm{c}$ & $109,988 \mathrm{~d}$ & 4.93 \\
\hline San Diego citrandarin & 2.41 & $10.21 \mathrm{~b}$ & 1.65 & $6,872 \mathrm{c}$ & $8,384 b$ & $13,170 \mathrm{a}$ & $19,111 \mathrm{a}$ & $34,986 \mathrm{~d}$ & $21,324 \mathrm{e}$ & $10,187 b$ & $114,034 d$ & 5.20 \\
\hline HTR - 051 & 2.40 & $9.75 b$ & 1.42 & $6,352 \mathrm{c}$ & $5,732 \mathrm{c}$ & $10,380 \mathrm{~b}$ & $13,928 b$ & $20,649 \mathrm{e}$ & $20,003 \mathrm{e}$ & $10,339 b$ & $87,383 \mathrm{e}$ & 5.16 \\
\hline LVK x LCR - 010 & 2.79 & $14.26 \mathrm{a}$ & 1.33 & $9,533 \mathrm{a}$ & $15,519 \mathrm{a}$ & $12,545 \mathrm{a}$ & $17,732 \mathrm{a}$ & $40,970 \mathrm{c}$ & $30,999 \mathrm{c}$ & $7,297 \mathrm{c}$ & $134,593 \mathrm{c}$ & 5.40 \\
\hline Means & 2.70 & 13.15 & 1.49 & 7230 & 10.582 & 11.405 & 16.388 & 40.281 & 28.474 & 9.436 & 114.360 & 5.39 \\
\hline CV (\%) & 12.52 & 21.51 & 15.64 & 17.10 & 15.81 & 8.29 & 11.59 & 7.88 & 8.24 & 21.17 & 10.58 & 24.58 \\
\hline $\mathrm{F}$ & $2.04^{\text {ns }}$ & $3.00 *$ & $1.57^{\mathrm{ns}}$ & $21.02 *$ & $14.96^{*}$ & $20.54 *$ & $11.66^{*}$ & $49.06^{*}$ & $32.45 *$ & $8.04 *$ & $65.77 *$ & $0.74^{\mathrm{ns}}$ \\
\hline
\end{tabular}

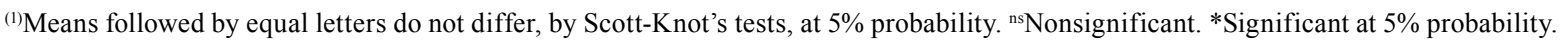

Table 2. Diameter (FD), height (FH), and rind thickness (RT) of fruit, juice content (JC), titratable acidity (TA), total soluble solids (TSS), vitamin C, technological index (TI), industrial yield (IY), and ratio of 'Jaffa' sweet orange in relation to rootstocks. Averages for 2014, 2015, and 2016 harvests $^{(1)}$.

\begin{tabular}{|c|c|c|c|c|c|c|c|c|c|c|}
\hline Rootstocks & $\begin{array}{c}\text { FD } \\
(\mathrm{mm})\end{array}$ & $\begin{array}{l}\text { Fruit height } \\
(\mathrm{mm})\end{array}$ & $\begin{array}{c}\mathrm{RT} \\
(\mathrm{mm})\end{array}$ & $\begin{array}{l}\mathrm{JC} \\
(\%)\end{array}$ & $\begin{array}{l}\text { TA } \\
(\%)\end{array}$ & $\begin{array}{c}\text { TSS } \\
\left({ }^{\circ} \text { Brix }\right)\end{array}$ & $\begin{array}{c}\text { Vitamin C } \\
\left(\mathrm{mg} \cdot \mathrm{L}^{-1}\right)\end{array}$ & $\begin{array}{c}\text { TI } \\
\left(\mathrm{kg} \mathrm{SST} \mathrm{cx}^{-1}\right)\end{array}$ & IY & $\begin{array}{c}\text { Ratio } \\
\text { TSS/TA }\end{array}$ \\
\hline Cravo Santa Cruz lime & $68.44 b$ & $44.47 \mathrm{~b}$ & 3.72 & $50.63 a$ & $0.99 \mathrm{a}$ & $12.21 \mathrm{a}$ & 57.59 & $2.52 \mathrm{a}$ & $261.90 \mathrm{a}$ & $12.54 \mathrm{a}$ \\
\hline Rugoso Vermelho lemon & $74.40 \mathrm{a}$ & $70.37 \mathrm{a}$ & 3.93 & $50.77 \mathrm{a}$ & $0.92 b$ & $10.54 \mathrm{c}$ & 54.37 & $2.18 b$ & $302.75 b$ & $11.73 b$ \\
\hline Orlando tangelo & $73.65 \mathrm{a}$ & $70.48 \mathrm{a}$ & 3.56 & $51.83 \mathrm{a}$ & $0.86 \mathrm{c}$ & $9.99 \mathrm{c}$ & 54.36 & $2.11 \mathrm{~b}$ & $312.79 b$ & $11.86 \mathrm{~b}$ \\
\hline Sunki Tropical mandarin & $71.11 \mathrm{a}$ & $67.92 b$ & 3.59 & $50.34 \mathrm{a}$ & $0.95 b$ & $11.13 \mathrm{~b}$ & 54.19 & $2.28 \mathrm{a}$ & $289.47 b$ & $11.80 \mathrm{~b}$ \\
\hline Indio citrandarin & $68.63 b$ & $67.56 \mathrm{~b}$ & 3.42 & $50.36 \mathrm{a}$ & $1.05 \mathrm{a}$ & $11.38 \mathrm{~b}$ & 53.12 & $2.33 \mathrm{a}$ & $283.26 b$ & $10.89 \mathrm{c}$ \\
\hline Riverside citrandarin & $71.95 \mathrm{a}$ & $69.52 \mathrm{a}$ & 3.50 & $51.40 \mathrm{a}$ & $1.02 \mathrm{a}$ & $10.96 b$ & 52.94 & $2.29 \mathrm{a}$ & $288.20 \mathrm{~b}$ & $11.09 \mathrm{c}$ \\
\hline San Diego citrandarin & $70.99 a$ & $68.70 \mathrm{~b}$ & 3.68 & $48.64 a$ & $1.01 \mathrm{a}$ & $11.06 \mathrm{~b}$ & 52.56 & $2.19 b$ & $301.36 b$ & $11.20 \mathrm{c}$ \\
\hline HTR-051 & $71.94 \mathrm{a}$ & $70.29 \mathrm{a}$ & 3.89 & $44.19 b$ & $1.02 \mathrm{a}$ & $11.51 \mathrm{~b}$ & 50.86 & $2.07 \mathrm{~b}$ & $318.84 b$ & $11.61 b$ \\
\hline LVK x LCR-010 & $72.10 \mathrm{a}$ & $68.82 b$ & 3.59 & $52.12 \mathrm{a}$ & $0.97 \mathrm{a}$ & $11.01 \mathrm{~b}$ & 56.06 & $2.34 \mathrm{a}$ & $282.05 b$ & $11.43 \mathrm{c}$ \\
\hline Means & 71.58 & 68.90 & 3.65 & 50.03 & 0.98 & 11.09 & 54.01 & 2.25 & 308.84 & 11.57 \\
\hline$\overline{C V}(\%)$ & 5.35 & 4.64 & 11.78 & 9.28 & 8.81 & 8.24 & 10.06 & 11.36 & 15.80 & 7.29 \\
\hline $\mathrm{F}$ & $3.26^{*}$ & $2.30 *$ & $1.87^{\mathrm{ns}}$ & $3.25^{*}$ & $5.76^{*}$ & $5.49 *$ & $1.59^{\mathrm{ns}}$ & $3.24 *$ & $3.21 *$ & $4.10 *$ \\
\hline
\end{tabular}

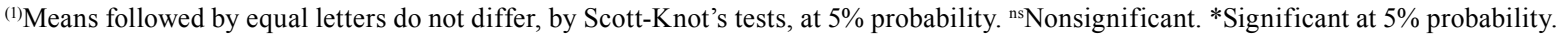


LCR-010 imparted higher TI values to 'Jaffa' than the remaining rootstocks. The average TI for all rootstocks was $2.25 \mathrm{~kg}$ TSS per box, which was higher than that obtained by Bacar et al. (2017).

Variables that were significant by the univariate analyses of variance and used for the multivariate analysis were: canopy volume (CV) and cumulative yield (CY, 2011-2017) for vegetative and productive performance and fruit diameter (FD); fruit height (FH); juice content (JC); titratable acidity (TA); total soluble solids (TSS); TSS/box; industrial yield (IY); and TSS/ TA ratio (ratio) for fruit quality. About $75 \%$ of the total variability could be explained by the first two PCA axes (Figure 1), and the square cosine of the variables

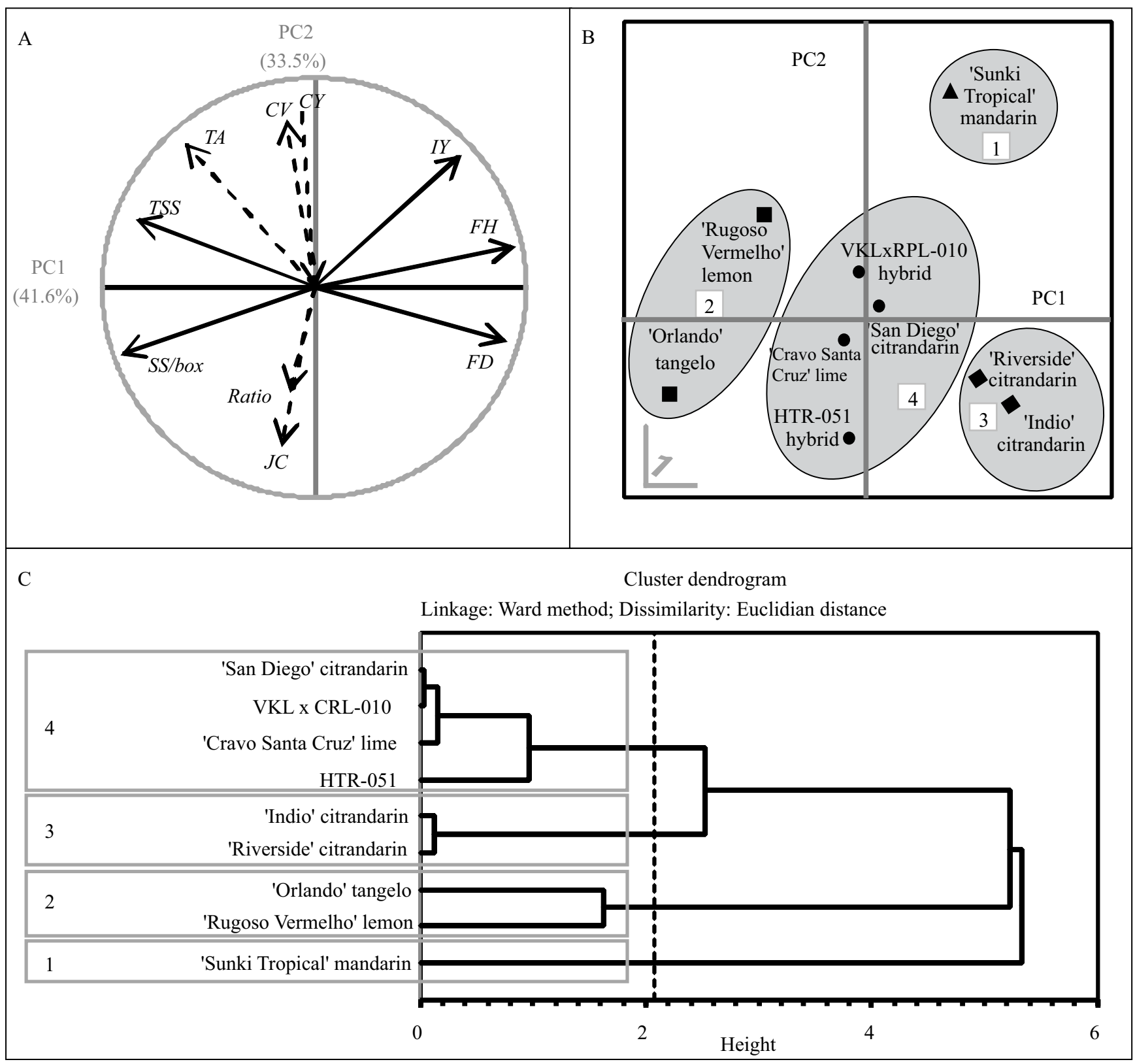

Figure 1. Representation of the four rootstock groups resulting from the principal component analysis and the agglomerative hierarchical clustering projected into the plane, defined by the first two principal component. In the correlation circle, straight lines represent variables that are the most explanatory of the PC1, while dashed lines represent variables that are the most explanatory of the PC2. A, correlation circle; B, Principal Component Analysis; and C, Agglomerative Hierarchical Clustering (AHC). 
showed that fruit diameter (FD), fruit height (FH), TSS, TSS/box, and IY were the most explanatory variables of PC1, whereas JC, TA, CV, and CY were the most explanatory variables of PC2. A significant positive correlation was observed between cumulative yields and canopy volumes, indicating that the greater the canopy, the higher the yield, especially because rootstocks did not significantly affect the yield efficiency of 'Jaffa'. Working with three different orange scions, Carvalho et al. (2019) identified that while the trifoliate rootstock HTR-051 induced dwarfism in 'Sincora', 'Valencia Tuxpan', and 'Pineapple', such dwarfism was associated with an increased yield efficiency (that is, mass of fruit per volume of canopy) only for 'Sincora', concluding that the adequacy to high-density plantings depends upon a scion/rootstock combination. In the present work, even though some rootstocks induced plants of small volumes, such dwarfism was not followed by an increased yield efficiency, which indicates that 'Jaffa' is not a sweet orange scion adapted to high-density plantings.

In general, fruit size [small diameter (FD), and height $(\mathrm{FH})$ ] were negatively correlated with TSS, TSS/box, and TA, indicating that bigger fruit normally showed low-Brix values and less acidity. Even though the correlation between fruit size (FD and $\mathrm{FH}$ ) and $\mathrm{CY}$ or JC could not be detected in the present study, the rootstocks that induced higher cumulative yields were also those that showed lower-juice contents in the fruit. The AHC grouped the rootstocks into four groups. The first group comprised only 'Sunki Tropical' mandarin, and was characterized by high cumulative yields. The second group included 'Orlando' tangelo and 'Rugoso Vermelho' lemon, and showed bigger fruit with low-Brix, low-SST/box, and less acid values. On the opposite, the third group, that included the 'Indio' and 'Riverside' citrandarins, tended to show more acid fruit, as well as low-cumulated yields and canopy volumes. Finally, the fourth group, that contained 'Cravo Santa Cruz' lime, 'San Diego' citrandarin, as well as the hybrids HTR-051 and LVK x LCR-010, shows mostly lower cumulative yields than the group 1 , and intermediate values for the other evaluated variables. This result indicates that while 'Sunki Tropical' mandarin is the best rootstock for promoting vegetative development and yield, the group composed by 'Cravo Santa Cruz' lime, 'San Diego' citrandarin, and the trifoliate hybrids HTR-051 and LVK x LCR010 induced fruit of better quality.
The rootstocks evaluated did not influence the population levels of the pest mites E. banksi $\left(\mathrm{F}_{8,27}=1.248 ; \mathrm{P}=0.3107\right)$, T. mexicanus $\left(\mathrm{F}_{8,27}=0.957\right.$; $\mathrm{P}=0.488)$, and P. oleivora $\left(\mathrm{F}_{8,26} 1.330 ; \mathrm{P}=0.272\right)$ in 'Jaffa'. Carvalho et al. (2016a) also did not found influence of rootstocks on the abundance of these mites in 'Piemonte' mandarin. In contrast, Silva et al. (2016) found high densities of $P$. oleivora on 'Pera CNPMF D-6' sweet orange grafted on x LCR-010, 'Cravo Santa Cruz' lime, and 'Rugoso Vermelho' lemon, which did not influence the population levels of the three pest mites in the present study.

\section{Conclusions}

1. 'Sunki Tropical' mandarin, 'Cravo Santa Cruz' lime, and 'Rugoso Vermelho' lemon are adequate rootstock options for 'Jaffa' sweet orange cultivation in Northeast Brazil, considering the vegetative, productive, and qualitative traits of 'Jaffa'.

2. The evaluated rootstocks do not influence the population levels of the pest mites E. banksi, $T$. mexicanus, and P. oleivora in 'Jaffa' sweet orange.

\section{Acknowledgments}

To Empresa Brasileira de Pesquisa Agropecuária (Embrapa), for financial support (SEG number 02.13.03.005.00.00).

\section{References}

ALMEIDA, C.O. de; PASSOS, O.S. (Ed.). Citricultura brasileira em busca de novos rumos: desafios e oportunidades na região Nordeste. Cruz das Almas: Embrapa Mandioca e Fruticultura, 2011. 159p.

AL-MOUEI, R.; CHOUMANE, W. Physiochemical juice characteristics of various citrus species in Syria. International Journal of Plant \& Soil Science, v.3, p.1083-1095, 2014. DOI: https://doi.org/10.9734/IJPSS/2014/10505.

BACAR, E.L.C.; NEVES, C.S.V.J.; LEITE JUNIOR, R.P.; YADA, I.F.U. TAZIMA, Z.H. 'Jaffa' sweet orange plants grafted onto five rootstocks. Revista Brasileira de Fruticultura, v.39, e-200, 2017. DOI: https://doi.org/10.1590/0100-29452017200.

CANTUARIAS-AVILÉS, T.; MOURÃO FILHO, F. de A.A.; STUCHI, E.S.; SILVA, S.R. da; ESPINOZA-NÚÑES, E.; BREMER, N.H. Rootstocks for high fruit yield and quality of 'Tahiti' lime under rain-fed conditions. Scientia Horticulturae, v.142, p.105-111, 2012. DOI: https://doi.org/10.1016/j. scienta.2012.05.008. 
CARVALHO, H.W.L. de; MARTINS, C.R.; TEODORO, A.V.; SOARES FILHO, W. dos S.; PASSOS, O.S. Agronomical performance of 'Piemonte' mandarin grafted on several rootstocks in the Brazilian Coastal Tablelands. Pesquisa Agropecuária Brasileira, v.51, p.1830-1838, 2016a. DOI: https://doi.org/10.1590/ s0100-204x2016001100005.

CARVALHO, L.M. de; CARVALHO, H.W.L. de; BARROS, I. de; MARTINS, C.R.; SOARES FILHO, W. dos S.; GIRARDI, E.A.; PASSOS, O.S. New scion-rootstock combinations for diversification of sweet orange orchards in tropical hardsetting soils. Scientia Horticulturae, v.243, p.169-176, 2019. DOI: https://doi.org/10.1016/j.scienta.2018.07.032.

CARVALHO, L.M. de; CARVALHO, H.W.L. de; SOARES FILHO, W. dos S.; MARTINS, C.R.; PASSOS, O.S. Portaenxertos promissores, alternativos ao limoeiro 'Cravo', nos Tabuleiros Costeiros de Sergipe. Pesquisa Agropecuária Brasileira, v.51, p.132-141, 2016b. DOI:_https://doi.org/10.1590/ S0100-204X2016000200005.

CEAGESP. Companhia de Entrepostos e Armazéns Gerais de São Paulo. Normas de classificação de laranjas. São Paulo, 2011. Disponível em: <http://www.ceagesp.gov.br/produtor/classif/fc_ laranja>. Accessed on: July 32017.

IBGE. Instituto Brasileiro de Geografia e Estatística. Produção Agrícola Municipal. Available at: <https://www.ibge.gov.br/ estatisticas/economicas/agricultura-e-pecuaria/9117-producao- agricola-municipal-culturas-temporarias-e-permanentes. html?edicao=16787\&t=sobre. Accessed on: Mar. 92016.

ISHFAQ, M.; HAFIZ, I.A.; HUSSAIN, A.; CHAUDHARY, G.A. Growth yield and fruit quality of sweet orange variety under rainfed condition of Chakwal. International Journal of Agriculture \& Biology, v.1, p.100-102, 1999.

SANTOS, H.G. dos; JACOMINE, P.K.T.; ANJOS, L.H.C. dos; OLIVEIRA, V.A. de; LUMBRERAS, J.F.; COELHO, M.R.; ALMEIDA, J.A. de; CUNHA, T.J.F.; OLIVEIRA, J.B. de. Sistema brasileiro de classificação de solos. 3.ed. rev. e ampl. Brasília: Embrapa, 2013. 353p.

SILVA, R.R. da; TEODORO, A.V.; VASCONCELOS, J.F.; MARTINS, C.R.; SOARES FILHO, W. dos S.; CARVALHO, H.W.L. de; GUZZO, E.C. Citrus rootstocks influence the population densities of pest mites. Ciência Rural, v.46, p.1-6, 2016. DOI: https://doi.org/10.1590/0103-8478cr20150486.

TEODORO, A.V.; MENDONÇA, M. da C.; NASCIMENTO, A.S. do; SILVA, L.M.S. da; FARIAS, A.P. Características e medidas de controle das principais pragas dos citros, nos estados da Bahia e Sergipe. Aracaju: Embrapa Tabuleiros Costeiros, 2014. 8p. (Embrapa Tabuleiros Costeiros. Comunicado técnico, 142).

VENDRAMIM, J.D.; GUZZO, E.C. Plant resistance and insect bioecology and nutrition. In: PANIZZI, A.R.; PARRA, J.R.P. (Ed.). Insect bioecology and nutrition for integrated pest management. Boca Raton: CRC Press, p.657-685, 2012. DOI: https://doi.org/10.1201/b11713-30. 